\title{
Flexible Fuel Vehicles: Powered by an American Fuel
}

Today, more than 5 million vehicles on U.S. highways are flexible fuel vehicles (FFVs). These vehicles can run on ethanol, a fuel manufactured in the United States. Made from home-grown crops and feedstocks, ethanol is the main ingredient in E85-a blend of 85\% ethanol and 15\% gasoline-which is both clean-burning and domestically produced.

Currently, the United States imports almost $60 \%$ of its oil, and each year petroleum consumption continues to increase. FFVs and E85 can play an important role in reducing U.S. dependence on foreign oil. These alternative transportation technologies help reduce conventional gasoline use, support American farmers, and have an overall positive effect on air quality.

\section{What is ethanol?}

Ethanol is an alcohol-based fuel produced by fermenting and distilling crops that are converted into simple sugars. In the United States, ethanol is typically made from starch crops, primarily corn. But it can also be made from sugar crops or agricultural waste and "cellulosic biomass," such as fast-growing trees and switchgrass. Ethanol has a high oxygen content, so it burns cleaner than gasoline. And because it is made from plants that absorb carbon dioxide as they grow, ethanol use results in reduced greenhouse gas emissions compared to gasoline. Plus, it degrades quickly in water and poses much less risk to the environment than an oil or gasoline spill.

Ethanol is primarily sold in two gasoline blends: E85, which is formulated for FFVs, and E10 (10\% ethanol, $90 \%$ gasoline), which is used in conventional vehicles. E10 accounts for more than $98 \%$ of ethanol sales in the United States, while E85 is a growing presence.

Ethanol is added to gasoline to boost its oxygen content and help reduce carbon monoxide emissions. Low-level ethanol blends are typically in the 7\%-10\% (e.g., E10) range. Compared to E10, E85 has many other environmental benefits. According to the U.S. Environmental Protection Agency (EPA), E85 produces fewer total toxins and lower levels of ozone-forming volatile organic compounds compared to gasoline. It also emits fewer emissions of oxides of nitrogen, or $\mathrm{NO}_{\mathrm{x}}$, and particulate matter.

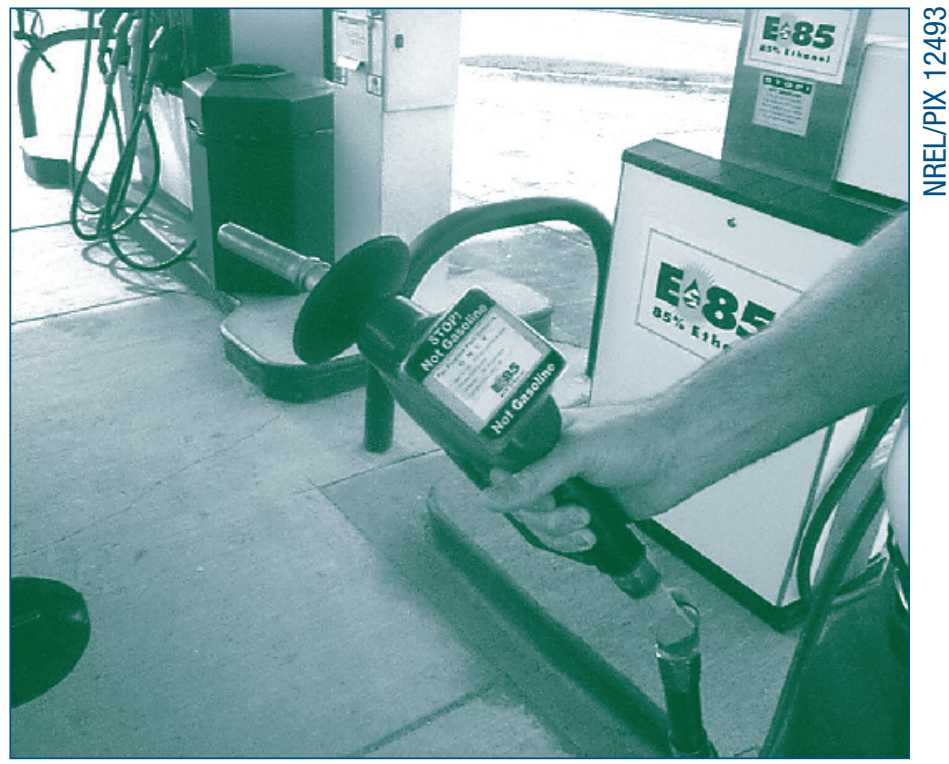

E85 pumps look much like gasoline dispensers, but their parts must be made of stainless steel to prevent corrosion.

The net energy contribution of ethanol has been a source of controversy. Numerous studies have demonstrated that corn ethanol has a "net positive" energy balance. A 2004 U.S. Department of Agriculture study concluded that the ratio of energy output to energy input is 1.67 , meaning that each unit of energy input used to produce ethanol leads to 1.67 units of energy generated in the form of ethanol*. Future production of ethanol from corn stover or cellulosic material will have an even better energy ratio. Studies that contradict these findings have typically been based on outdated assumptions or non-standard economic analysis.

\section{What is an FFV?}

Like conventional gasoline vehicles, FFVs have a single fuel tank, fuel system, and engine. The engine and fuel system are slightly adjusted to run on gasoline, E85, or a mixture of the two. (Today's light-duty FFVs generally require at least $15 \%$ gasoline in the mixture, mainly for cold start purposes.) For optimal operation, a sensor in the system analyzes the fuel composition and adjusts the fuel injection and ignition.

*www.usda.gov/oce/reports/energy/net_energy_balance.pdf 
Clean Cities posts a list of alternative fuel vehicles, including FFVs, on its Alternative Fuels Data Center (AFDC) Web site. To find out what models are now available, visit $w w w$. eere.energy.gov/afdc/afv/models.html, and choose the current model year.

\section{How does E85 affect vehicle performance?}

Reduced fuel economy is the only real performance difference between E85 and gasoline vehicles. This is because ethanol contains less energy per gallon than gasoline. But fuel economy is affected by a variety of factors, including driving habits, weather, fuel composition at the pump, (e.g., the proportion of ethanol may be closer to 70\% in colder states in the winter), and the percentage of E85 versus gasoline in the fuel tank. Standard testing results for fuel economy of FFVs and their gasoline counterparts are posted on the combined EPA and U.S. Department of Energy Web site at www.fueleconomy.gov. Real-life fuel economy is affected by the factors previously noted, which can result in variances from the standard test results.

\section{What are the costs of using E85?}

The cost of using E85 is comparable to that of conventional fuel. Because E85 fueling capability adds little or nothing to the purchase price of FFVs, it often comes standard or is offered as a no-cost option. And, since FFVs have been used in private and government fleets for years, the technology is proven. Therefore, manufacturers stand behind FFVs with standard warranties equal to those of gasoline vehicles.

The one performance difference in the vehicles, reduced fuel economy of E85, is often offset in whole or in part by the fuel's lower price per gallon.

\section{How do manufacturers label FFVs?}

The Energy Policy Act of 2005 requires auto manufacturers to adhere a label inside the FFV fuel compartment that states that the vehicle is capable of running on E85 and gasoline. (These labels are required on vehicles made on or after September 1, 2006.) Flexible-fuel capability is also outlined in the vehicle owner's manual and encoded in the vehicle identification number, or VIN. For more information on FFV labeling, visit the National Ethanol Vehicle Coalition (NEVC) Web site at www.e85fuel.com.

Sponsored by the U.S. Department of Energy

Energy Efficiency and Renewable Energy

FreedomCAR and Vehicle Technologies Program

For more information contact: EERE Information Center

1-877-EERE-INF (1-877-337-3463)

www.eere.energy.gov

A Strong Energy Portfolio for a Strong America

Energy efficiency and clean, renewable energy will mean a stronger economy,

a cleaner environment, and greater energy independence for America. Working

with a wide array of state, community, industry, and university partners, the

U.S. Department of Energy's Office of Energy Efficiency and Renewable Energy invests in a diverse portfolio of energy technologies.

DOE/GO-102006-2291 • February 2006

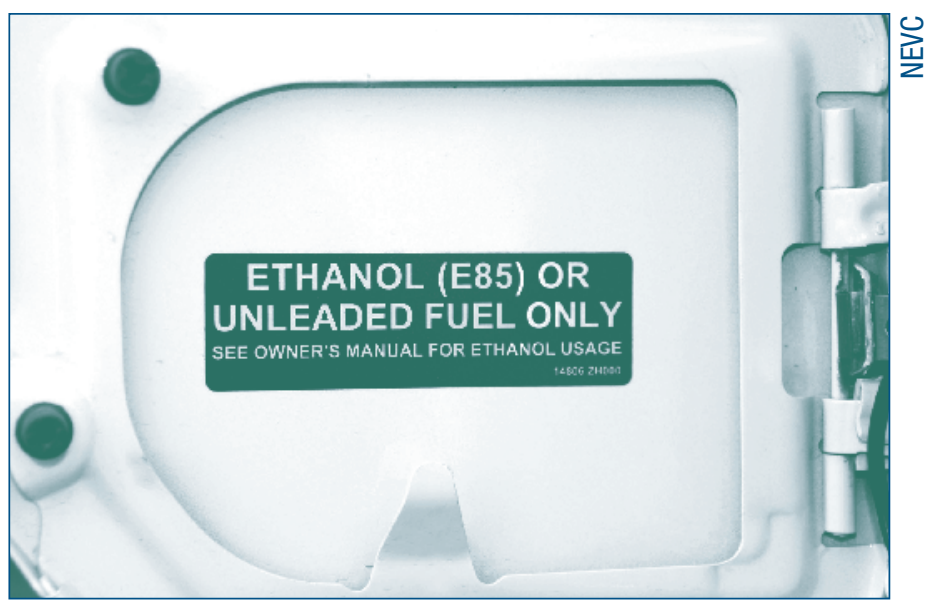

Automakers must adhere a label inside the FFV fuel compartment stating the vehicle's ability to run on E85 or gasoline.

\section{Where are E85 stations located?}

Ethanol production and distribution infrastructure continues to expand across the nation. At the end of 2005, E85 was sold at more than 500 stations in over 35 states-a four-fold increase in fueling sites since 2003. To find E85 stations throughout the country, use the Alternative Fuel Station Locator at www.eere.energy.gov/afdc/infrastructure/ locator.html, which is maintained by Clean Cities' AFDC. The site also allows users to plot maps from point to point, either across town or across the nation, showing E85 stations along the way.

\section{Resources}

Clean Cities: www.eere.energy.gov/cleancities

Vehicle Buyer's Guide: www.eere.energy.gov/cleancities/vbg

AFDC: www.eere.energy.gov/afdc/altfuel/ethanol.html

E85 Fleet Toolkit: www.eere.energy.gov/e85toolkit

EPA: www.epa.gov/otaq/consumer/fuels/altfuels/420f00035.pdf

NEVC: www.e85fuel.com

American Coalition for Ethanol: www.ethanol.org

Renewable Fuels Association: www.ethanolrfa.org

Prepared by the National Renewable Energy Laboratory (NREL)

NREL is a U.S. Department of Energy National Laboratory

Operated by Midwest Research Institute • Battelle

Neither the United States government nor any agency thereof, nor any of their employees, makes any warranty, express or implied, or assumes any legal liability or responsibility for the accuracy, completeness, or usefulness of any information, apparatus, product, or process disclosed, or represents that its use would not infringe privately owned rights. Reference herein to any specific commercial product, process, or service by trade name, trademark, manufacturer, or otherwise does not necessarily constitute or imply its endorsement, recommendation, or favoring by the United States government or any agency thereof. The views and opinions of authors expressed herein do not necessarily state or reflect those of the United States government or any agency thereof.

Printed with a renewable-source ink on paper containing at least $50 \%$ wastepaper, including $10 \%$ postconsumer waste. 